Frančiška Trobevšek Drobnak

University of Ljubljana

Slovenia
2015, Vol. 12 (2), 99-112(244)

revije.ff.uni-lj.si/elope

doi: 10.4312/elope.12.2.99-112

UDC: $811.111^{\prime} 367.625: 81^{\prime} 367.4$

\title{
Iconicity and Distribution of Complex Verbal Phrases in English
}

\begin{abstract}
The aim of the paper is to look into how the use and distribution of complex verbal phrases in English comply with the postulates of the theories of constructional iconicity, frequency asymmetries and naturalness, especially in the initial stages of their proliferation. The three theoretical frameworks are first outlined and compared, and predictions ensuing from them are formulated as to the expected behaviour of complex versus simple linguistic constructions. Two types of complex verbal constructions are examined from the point of view of these predictions: the progressive verbal phrase be + present participle and the composite predicate consisting of a semantically bleached verb + deverbal noun.
\end{abstract}

Keywords: iconicity; frequency; naturalness; progressive; composite; deverbal

\section{Ikoničnost in raba opisnih glagolskih zvez $\mathbf{v}$ angleščini}

POVZETEK

Osnovni namen članka je ugotoviti, ali in kako se raba opisnih glagolskih zvez v angleščini ujema z napovedmi konstrukcijskega ikonicizma, s pogostnostjo pogojenimi jezikovnimi asimetrijami in z napovedbmi jezikovne naravnosti. Postulati omenjenih teorij so najprej na kratko opisani, nakar so iz njih izpeljane napovedi o pričakovanem vedenju opisnih glagolskih zgradb v primerjavi z enostavnimi glagoli. Dve vrsti angleških glagolskih opisnih zgradb sta analizirani $s$ stališča omenjenih napovedi: glagolska zveza biti + deležnik sedanjika ter glagolsko-samostalniška zgradba pomensko ošibljeni glagol + izglagolski samostalnik.

Ključne besede: ikoničnost; pogostnost; naravnost; progresivni; sestavljeni; izglagolski 


\section{Iconicity and Distribution of Complex Verbal Phrases in English}

\section{Introduction}

The emergence and the proliferation of complex verbal constructions in English have been discussed mostly from the point of view of their meaning (Wierzbicka 1982; Nickel 1978) and/or collocations (Akimoto 1989), but as conclusive as the findings may be the propensity of speakers to choose a complex verbal phrase over its simple alternative, to favour "packing thinner [semantic] bundles into two or more words" (Bolinger 1971, 45), remains elusive in many contexts. The theories of linguistic iconicity, of frequency asymmetries and of linguistic naturalness all suggest that the choice between two linguistic variants depends (also) on their respective outer forms. The present paper examines the validity of the predictions of these theories by exploring whether (and if so, to what extent) they comply with the emergence and proliferation of the construction be + present participle in the English language, and whether or not comparable results would be found in a formally similar construction, the combination of a semantically bleached verb with a deverbal noun.

The paper first outlines the postulates of the theories of linguistic iconicity, frequency asymmetries and naturalness, as well as their predictions about the expected behaviour (distribution) of formally less or formally more elaborate linguistic variants. The diachronic aspect of the predictions ensuing from each of the theories is also summarized. Complex verbal phrases may be qualified as formally more elaborate linguistic variants of simple verbal structures, especially in contexts where both are acceptable or even synonymous. In the broadest sense of the word, a complex verbal phrase is any structure which consists of more than a simple verb and acts as a predicate, including periphrastic tenses, phrasal verbs and combinations of semantically bleached verbs with deverbal nouns. The paper then introduces the periphrastic verbal phrase be + present participle, and predictions ensuing from the above theories are applied as to emergence, expansion and functions of the construction from Old English to Modern English. The construction has been chosen because of its attested interchangeability with corresponding simple verbal phrases (at least) in initial stages of its assertion in Old English. The absence of any meaningful contrast between two constructions makes the relevance of other factors, such as grammatical environment, more discernible. The predictions are compared with the relevant findings of previous studies of the use and function of the construction (Trobevšek Drobnak 1990; Elsness 1994; Dennis 1940; Ranta 2006).

If the behaviour of the verbal phrase be + present participle complies with the predictions of the three theories applied - and this is to be interpreted as contingent on its outer form - similar results should be obtained in the case of other elaborate verbal constructions. For the purpose of this paper, the combination of a semantically bleached verb and a deverbal noun has been chosen, mainly because of its near-synonymy with a corresponding simple verb, and the elusive rules of its use. The emergence, the proliferation and the function of this construction from Old English to Modern English are therefore described and assessed from the point of view of the predictions of the theories of iconicity, frequency asymmetries and naturalness, and the findings are compared with those pertaining to the construction be + present participle. The findings of earlier studies are used to that effect (Akimoto 1989; Matsumoto 2005; Iglesias-Rabade 2001; Wierzbicka 1982). A pilot analysis of the grammatical environment of all the instances 
of semantically bleached verbs with deverbal nouns in Oscar Wilde's play The Importance of Being Earnest is added, in order to assess the affinity of the construction for a more complex grammatical environment, as predicted by the theory of naturalness.

\section{Iconicity, Frequency Asymmetries and Naturalness}

Linguistic iconicity is broadly described by cognitive linguists as "the intuition [...] that the structure of language reflects in some way the structure of experience" (Croft 1990 [2003], 102). Greater quantities are so referred to by longer expressions (iconicity of quantity), meanings that are related are expressed by more cohesive forms (iconicity of cohesion), and more complex meanings are conveyed by more complex formal structures (iconicity of complexity) (Haspelmath $2008,1-2)$. Of all the types, iconicity of complexity is the one most frequently suggested as the possible motivation behind the choice of formally more or less elaborate structures.

The iconicity of complexity (also called constructional iconicity) has been defined as the correlation between marked meanings and marked forms (Jakobson 1963 [1966], 270). The notion of markedness was introduced by the Prague School in the 1930s. It has survived to this day, but it can be further understood in at least twelve different senses (Haspelmath 2006, 31). Applied in phonology, it first referred to specification for phonological distinction (Trubezkoy 1931), but more recent authors define it in terms of difficulty of articulation and lower frequency within and across languages (Haspelmath 2006, 26). Outside phonology, a distinction has been made between formal and semantic markedness. Formal markedness generally means "overtly expressed". Semantic markedness, which extends to different values of grammatical categories, is measured either by the number of features needed to describe the meaning of an expression (Lehmann 1974) or as specification for semantic distinction. So, for example, Jakobson (1957 [1971]) describes the perfective aspect in Russian as marked in comparison with the imperfective aspect, since the former refers specifically to the completion of the event and the latter is noncommittal in that respect. Other expressions used with respect to constructional iconicity are (correlation between) "semantic complexity" of a sign and its "phonological representation" (Lehmann 1974, 111), "a larger chunk of information" and a "larger chunk of code" (Givon 1991), "conceptual intensity" and "morphological expression" (Haiman 2000, 283).

Typical examples of isomorphism between semantic complexity and formal expression of grammatical categories in English are: ${ }^{1}$

PLURAL number as opposed to SINGULAR number (girl : girl-s)

GENITIVE case as opposed to NOMINATIVE case (children : children-'s),

FEMALE gender as opposed to MALE gender (lion : lion-ess)

PAST tense as opposed to PRESENT tense (work : work-ed)

NEGATIVE polarity as opposed to AFFIRMATIVE polarity (is : isn't)

IMPERFECTIVE as opposed to PERFECTIVE/AORISTIC aspect (wrote : was writing), etc.

Mayerthaler (1981, 11-12) and Orešnik (et al. 1990, 7-8) propose that the singular is less marked than the plural, the present tense is less marked than the past tense marked, the positive polarity less marked than the negative, etc. 
The notions of markedness and constructional iconicity are brought up in the theory of linguistic naturalness. This theory was first formulated as natural phonology (Stampe 1979; Donegan 1985) and natural morphology (Mayerthaler 1981; Dressler 1987), later extended to syntax (Ryden 1979), and eventually it became a language-universal theory (Dotter 1990; Orešnik et al. 1990; Dressler 2000). Naturalists currently operate with the terms naturalness scale, sem-values and symvalues (Mayerthaler 1988; Orešnik 2004). The naturalness scale rests on the assumption that, from the speaker's point of view, some morphosyntactic structures are more natural (<nat) than others (>nat), since the latter "strain the human language capacity" (Wurzel 1998, 63). A typical $<$ nat construction is formally less elaborate, bending to the principle of least effort (Havers 1931, 171). Mayerthaler (1981) divided the naturalness scale into the one referring to the symbolic (formal) properties (sym-values) and the one referring to the semantic properties (sem-values) of linguistic constructions.

It has been a common assumption that semantic complexity equals cognitive complexity, the amount of attention, mental effort and time needed for information processing (Givon 1991, 337), which prompts the choice of a formally more elaborate structure over the economical one: "All other things being equal, a coded experience is easier to store, retrieve, and communicate if the code is maximally isomorphic to the experience" (Givon 1985, 189). The discrepancy between semantic complexity and cognitive difficulty may result in wrong predictions of constructional iconicity. So, for example, the feminine gender is traditionally considered to be more marked (more specified and restricted) than the masculine, but feminine forms may be shorter than corresponding masculine ones (e.g. FEMALE widow vs. MALE widow-ER). According to Haspelmath $(2008,7)$ the problem can be resolved if frequency is brought to the equation.

That frequency asymmetries can explain formal asymmetries was argued already by Greenberg (1996), who found out that marked constructions are less frequent universally across languages. The following order of frequency has been established for different values of grammatical categories across languages (Haspelmath 2002):

NUMBER:

CASE:

PERSON:

DEGREE:

VOICE:

MOOD:

POLARITY:

TENSE:

$$
\text { singular }>\text { plural }>\text { dual }
$$

nominative $>$ accusative $>$ dative

$$
3 \text { rd }>\text { non-3rd (1st and } 2 \text { nd) }
$$

positive $>$ comparative $>$ superlative

active $>$ passive

indicative $>$ subjunctive

affirmative $>$ negative

present $>$ future

Haspelmath believes that "the great majority of universal morphosyntactic asymmetries are economically motivated [...]. Economical coding is functionally motivated if it occurs with frequently expressed meanings" (Haspelmath 2008, 2-3). This explains why complementary prototypes, i.e. typical associations of a particular value of a given category $x$ with a particular value of another category $y$, behave differently than their respective constituent parts. Example: [2 $2^{\text {ndPERSON }}$, IMPERATIVE] constitutes a more frequent association of person and mood than 
[3 $3^{\text {rdPERSON }}$, IMPERATIVE], hence the more economical Run!, as opposed to the more elaborate Let him/us/them run!. The main effect of frequency is predictability. The relation between (un) predictability and the required amount of encoding material is iconic (Givon 1991, 87). Rather than ruling it out, the principle of frequency asymmetry and economy complements the iconicity of complexity. Furthermore, frequency could be one of the major factors contributing to the naturalness of "some phenomena [being perceived] more easily than others" (Wurzel 1994, 2592).

\section{Distribution of Alternative Constructions: Diachron- ic Aspect}

There are several (potential) phases of language change:

(1) Innovation: any type of alteration of the language configuration - either the rise or the loss of any feature of phonemic, morphological, syntactic or lexical material. It may be externally or internally motivated. ${ }^{2}$ The two labels should not be understood as forming a mutually exclusive dichotomy, but rather as referring to two possible sources which can be identified in a language change, the description of whose differential interaction is an essential part of accounting for this change (Hickey 2012, 402-3).

(2) Coexistence of pairs of competing linguistic variants which differ on the level of expression, but their respective functions may overlap and in certain contexts they are interchangeable. Within the framework of constructional iconicity, one member of such a pair may be described as formally more marked and the other one as formally less elaborate or unmarked.

(3) Expansion of the new linguistic feature/structure. On diachronic level, the theory of naturalness posits that the behaviour of a linguistic innovation depends on how its outer form compares to the form of the "older" alternative construction. If the innovation is formally more elaborate (more marked), it will be, post status nascendi, favoured in "difficult" environment, which stretches beyond the extra-linguistic or contextual circumstances of communication into the complexity of the immediate grammatical environment. A weaker (less elaborate) alternative spreads faster (or survives longer) in an "easy" environment, which includes a less complex grammatical environment (Orešnik, et al. 1990, 5-11).

(4) Regularisation of the function of competing alternative structures. As the new linguistic structure spreads, its interchangeability with the older structure may give way to specialized (diverging) function(s). The prediction based on the postulates of constructional iconicity is that the formally more marked structure would eventually assume the function of expressing the more marked (complex) meaning, if compared with the function assumed (or retained) by its less marked alternative. The prediction ensuing from frequency based postulates is that formally more elaborate structures would "specialize" for less frequently evoked meaning(s), and formally less elaborate structures would be preferred with more frequently evoked meaning(s).

\section{Composite Predicate: be + present participle}

The periphrastic construction be + present participle has been most frequently referred to as expanded, progressive or continuous, of which the term progressive seems to be universally accepted

Externally-motivated language change is induced by sociolinguistic factors, a typical example of which is language contact. An example of an internally-motivated change is grammatical restructuring due to phonetic weakening or loss. 
nowadays. In this paper it will be referred to as progressive verbal phrase (PVP), although in Old English this construction was not consistent in portraying the action as being in progress.

The Old English construction consisting of the verb beon/wesan + present participle can be found in the oldest English manuscripts. While there are only four instances of it in Beowulf (Klaeber 1950), it is relatively frequent in texts translated from Latin. Mossé attributes them to either direct or indirect influence of Latin:

Quelles que soient leur nature, leur dates et leur origins, poésie ou prose, traductions ou originaux, tous les textes du vieil-anglais nous ont été transmis sous la forme que leur avaient donnée des clercs, c'est-à- dire des lettrés qui tous savaient le latin. (1938, 53-54).

According to Mossé, the introduction of this construction was further motivated by the collapse of the old Germanic system of the lexical aspect in verbs (Aktionsart). Nickel (1966, 83-207), on the other hand, dismissed the influence of Latin as the main instigator of the construction since he found no correlation with comparable constructions in the original Latin texts. In Orosius, dating probably from about CE 890, PVP is relatively independent from Latin: of 237 instances in the Old English text, 131 correspond to simple verbal phrases (SVP) or have no equivalent in the Latin original (Mosse 1938, 66; Nickel 1966, 112) and 154 are rendered as SPV in either or both of the Modern English translations (Nickel 1966, 330-51). Traugott also points to examples of Old English PVP in Orosius which would definitely be rendered as SVP in Modern English (Traugott 1972, 90).

The electiveness of PVP in Orosius provides sufficient argument for this construction to be treated as a syntactic variant (alternative) of a corresponding simple verbal phrase (SVP) in Old English.

On the basis of the postulates of linguistic theories described above, the following predictions can be formed as to the assertion of PVP in English:

(1) In Old English PVP was formally more marked than SVP.

(2) In Old English PVP was less frequent than SVP.

(3) In Old English PVP was favoured in grammatically complex environment.

(4) When not (no longer) interchangeable with SPV, PVP assumed semantically more marked meaning(s).

The Old English finite verbal phrase (SVP) typically consisted of a verbal stem and a personal ending, both in the present and in the preterite tense, in the indicative and in the subjunctive mood. Its Modern English formal descendent is the Present/Past Simple Tense form. The Old English PVP consisted of the auxiliary beon/wesan in the appropriate form, the present stem of the verb and the participial ending -ende. When compared with the Old English SVP, Old English PVP may be described as formally marked, and Old English SVP as a formally unmarked linguistic construction. To account for the distinction between formal and semantic markedness, the qualifier $<$ form will be assigned to PVP and the qualifier $>$ form to SPV in this paper.

Old English PVP was much less frequent that SPV: in Orosius (Sweet 1883 [1959]) there are 237 clauses containing PVP and 2565 clauses with simple SVP (Trobevšek Drobnak 1990). In Shakespeare, Marlow and Milton, the construction is still rarely found, but it has been gaining ground, especially after 1700. Dennis $(1940,856)$ reports that the Gospel according to St Mark 
contains 29 instances of PVP in the King James Bible from 1611, and that all but one of these instances are kept in their progressive form in a 20th-century version of the Bible, with the addition of 78 new cases of PVP, formerly rendered as SPV.

The validity of the hypothesis of the theory of naturalness, that Old English PVP were initially favoured in grammatically complex environment, was tested on the use of PVP in the Old English translation of Historiarum Adversus Paganos by the historian and theologian Orosius). ${ }^{3}$ The basic sample consisted of 237 clauses with PVP as the predicator, and the control sample consisted of 855 clauses with SPV as the predicator. The probability rates of any chosen grammatical category for assuming a particular value was computed for the basic and for the control sample. The grammatical environment of selected constructions was determined as to its scope (e.g. sentence, clause, matrix verbal phrase) and as to the observables. Initially, these were traditional grammatical categories which were assigned binary values - one defined as constituting a more complex $(<\mathrm{com})$, and the other as constituting a less complex (>com) grammatical environment. In the absence of other reliable criteria, the attribute <com was assigned to the marked values of grammatical categories, as proposed by the Prague School (Jakobson 1932) and by natural morphologists (Mayerthaler 1981). ${ }^{4}$ Subordinate clauses, negative propositional modality, preterite tense, nonindicative (subjunctive or imperative) mood, imperfective aspect, plural number and transitivity of the verb were presumed as <com grammatical environment. Four out of eight grammatical parameters (the tense, the aspect, the type of object ${ }^{5}$ and the grammatical number of the subject) assumed more frequently the $<$ com value in the environment of PVP (the $<$ form construction), while four parameters (the propositional modality, the type of clause, the mood, the transitivity) assumed the <com value more frequently in the environment of SPV (the $>$ form construction). The predictions based on the postulated of the theory of naturalness were confirmed in the case of the tense, the aspect, the type of verbal complementation (object) and the number. The propensity of < form for <com grammatical environment is thus indicated, but not consistently so for all grammatical categories. The validity of the results for the propositional modality and the mood is reduced by the low occurrence of the negative polarity and the subjunctive mood in both samples (below 10 percent). The absolute prevalence of the imperfective aspect in the basic sample cannot be treated as "environmental", but rather as the intrinsic value of the construction. Despite the indefinite value of many Old English PVP, the construction containing a present participle was never completely devoid of its "imperfectiveness". The results for the tense are corroborated by Elsness' findings (1994, 11). He examined the Modern English section of the Helsinki Corpus and found out not only that the frequency of PVP was higher in the preterite than in the present tense, but also that it grew at a faster rate in the preterite throughout the Modern English period.

According to Jespersen (Jespersen 1931, 164-234), Modern English progressive forms arose from the fusion of the structure be + present participle with the Middle English innovation be + on + gerund. It is commonly accepted that PVP is primarily intended to emphasise durative aspect and temporariness, "freezing" the flow of time and focusing on the internal temporal structure of an action. Numerous studies, however, have showed that the use of PVP in Modern English stretches beyond aspectual considerations into stylistics, reflecting the speaker's desire to make what they say "more lively and vivid" (Potter 1975, 120). Mair and Hundt's corpus-

\footnotetext{
The results of the research were first published in Trobevšek (1990).

Unlike Mayerthaler's sem-values, with which they share the ground of common markedness, the <com and >com labels were used for the assessment of the complexity of grammatical environment of chosen constructions, and not for the evaluation of the complexity of constructions themselves.

Prepositional phrase as a complement to a transitive verb was assigned the qualifier $<$ com.
} 


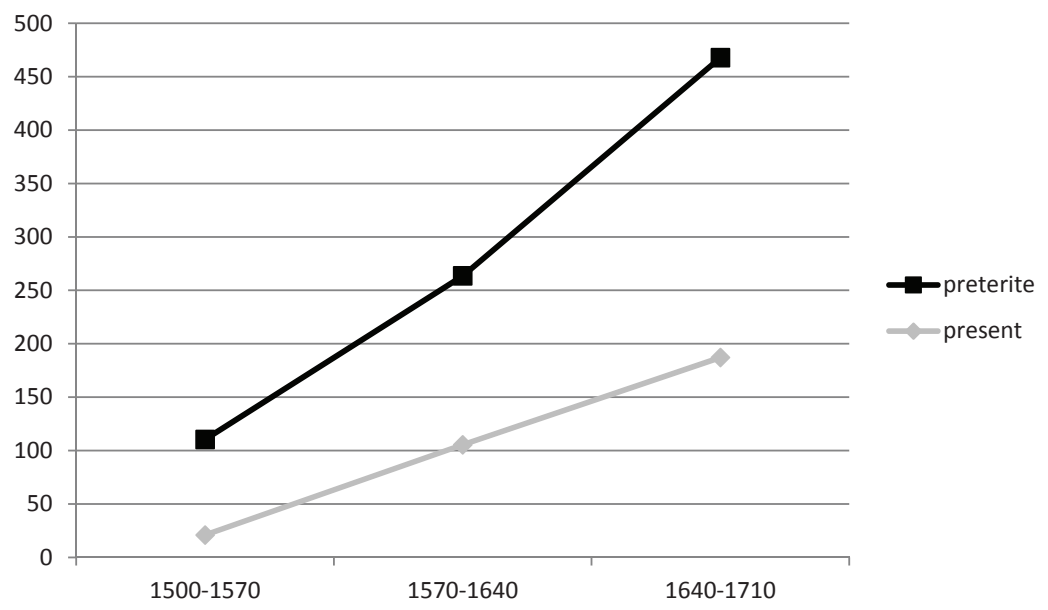

Figure 1. The frequency of PDT in Modern English, Helsinki Corpus, cases per 1000 clauses.

based studies demonstrate an increased use of PVP over the last decades, especially in spoken English. They suggest that the reason is "a textlinguistic or stylistic one" and that it might be led by the affective-emotional use of the progressive (as in You're always complaining) (1995, 118-19). Haspelmath (1999) calls such motivation impressive, arguing that this can eventually result in language change. The impressive value of PVP seems to be particularly salient in stative verbs, where the aspectual, i.e. durative or progressive component is inherent and does not need additional formal marking. It is worth noting that the use of PVP is highest in L2 speakers. In her ELFA-corpus based ${ }^{6}$ study Elina Ranta (2006) finds that the extended use of PVP in L2 speakers is not restricted to stative verbs only, but also used in contexts that are considered "deviant" from the standard. She believes that the progressive form is preferred by L2 speakers because of its communicative value, which comes from its prominence and salience $(2006,111)$.

From the point of view of constructional iconicity it matters little whether PVP specifies the action referred to for its temporal structure or emotional emphasis. In both cases the longer form expresses semantically more marked content if compared with SPV, which is non-committal in that respect.

\section{Composite Predicate: verb + deverbal noun}

One of the most productive composite predicates in Modern English is the combination of a semantically bleached verb with a deverbal noun. The term semantically bleached (semantic bleaching) is here used in its traditional sense of desemantisation, and refers to verbs such as have, take, get, make, do, give, the semantic range of which is relatively wide to begin with, but when used with deverbal nouns they lose to a great degree their specific configuration and display evidence of grammaticalisation in progress. The designation of such composite predicates varies: from complex verbal structure or complex verb (Olsson 1961; Nickel 1968) composite predicate (Cattel 1984), verbo-nominal structure (Akimoto 1989) to expanded predicate (Algeo 1995). In this paper, the abbreviation VNP (as in "verbo-nominal predicate") will be used for clarity's sake.

ELFA corpus contains 1 million words of transcribed spoken academic ELF. 
The VNP construction shares the following features with PVP:

(1) Both constructions can be found in the oldest extant English texts, but they are rarely attested there, and their growing frequency is commonly interpreted as evidence of the analytical tendencies in the English language during the late Middle English and New English periods (Bacchielli 1993).

(2) When compared to corresponding simple verbs, both constructions seem to convey some intrinsic aspectual or telic meaning, but not consistently so, and in some contexts they may be regarded merely as formally more elaborate alternatives to simple verbs.

(3) The criteria of the actual use of PVP and of VNP are rather elusive. The theories of linguistic iconicity, frequency based asymmetries and naturalness make tentative predictions about circumstances that favour them over their formally simple alternatives.

Given the similarities between VNP and PVP, and on the basis of the postulates of linguistic theories outlined in section 1, the following hypotheses pertaining to VNP can be formulated and tested:

- As a periphrastic construction, VNP is formally more marked and therefore less frequent than corresponding SVP.

- When not interchangeable with SPV, VNC is semantically more marked than SPV.

- When interchangeable with SVP, VNP is favoured in grammatically more complex environment.

Combinations of the verbs (ge)don, (ge)macian, sellan, giefan, habban, niman and takan with deverbal nouns can be found in Old English, but they are rare and scholars such as Mitchell (1985) or Visser (1963 [1970]) make no or little reference to them. Akimoto and Brinton (1999) identified 114 instances of VNP in Old English, ${ }^{7}$ namely as collocations of deverbal nouns with five verbs (don and macian, sellan and giefan, habban, niman). The verb don was found to collocate with 50 different nouns, habban with 22, niman with 18, sellan with 15, macian with eight, and giefan with one noun $(1999,44)$. In 77 of 114 instances synonymy with corresponding SVP was established. In all other cases, the use of NVP had an "intransitivizing effect" (Akimoto and Brinton 1999, 44). The Old English VNP may have been used for stylistic effect to reproduce Latin originals, ${ }^{8}$ or it may have been motivated by modification and coordination, without serving any aspectual function (Akimoto 1989, 51).

In Middle English, there is a remarkable growth of VNP in the 14th century. The Middle English Dictionary thus lists 148 new construction, which Iglesias-Rábade $(2001,161)$ sees as a manifestation of French influence on English. His conclusion is corroborated by a particularly great increase of VNP with the verb maken, possibly emulating the French construction faire + deverbal noun (Matsumoto 2005). In Middle English, VNP is found more frequently in poetry than in prose, and it is more common in drama and romance than in technical or religious texts (Matsumoto 2005, 153).

The research was based on A Microfiche Concordance of Old English by Venetzky and Healy (1980), as well as on Anglo-Saxon, Middle English and Modern English dictionaries.

8 Most of gedon VNP found in translations corresponded to Latin VPN with the verbs agere or facere. 
In Modern English, VNP is considered to be one of the most productive structures (Goerlach 1919). It has been a widely spread belief that "it is a feature of informal language" (Quirk et al. 1985, 75-52). Wierzbicka $(1982,557)$ believes that NVP is highly colloquial, and that technical, very formal [deverbal nouns] cannot be used in such constructions. ${ }^{9}$ By contrast, Lareo (2008) found it more frequent in scientific than in fictional prose. ${ }^{10}$ When compared to SVP, VNP remains less frequent in all registers. Lareo reports 85 instances of VNP and 563 SVP per 100,000 words in the science corpus, compared to 74 VNP and 223 SVP per 100,000 words in the fiction corpus (Lareo 2008, 176). In Oscar Wilde's The Importance of Being Earnest, first performed in 1895, there are only 17 instances of VNP with the verb have, two instances with the verb take, two instances with the verb give and two instances with the verb make. The verb have is used with deverbal nouns doubt (5), intention (1), knowledge (1), influence (2), amusement (1) and proof (1), all of which occur also as SVP in the text. The deverbal nouns relapse (1), fascination (1), occupation (1), stroll (2) and surprise (1) are used with the verb have, but no corresponding SVP are found in the text. The verb take is used once with seat and once with notice, the verb give is used twice with consent, and the verb make once with allusion and once with arrangement. Of these, only notice and allude are found also as SVP.

One of the possible motives behind the use of VNP instead of a simpler SVP is the ease of modification of deverbal nouns with adjectives, possessives, quantifiers, and even relative clauses (Nickel 1978, 77). Quirk (1985) suggests that VNP also allows more flexibility from the point of view of functional sentence perspective, like shifting the focus of attention from one complement to another (give Mary a kiss, give a kiss to Mary : kiss Mary). Of the 17 instances of have-VNP in Wilde's play, 14 are modified, as is the make-VNP and one of two take-VNP, but none of two give-NVP.

Wierzbicka $(1982,757)$, insists on the semantic difference between VNP and SVP. The most consistent function of VNP seems to be aspectual: it expresses limited duration, perfectivity and telicity (Prince 1972); the construction is considered to be "agentive, experience-oriented, antidurative, atelic and reiterative" (Wierzbicka 1982, 759). The conversion of activities into accomplishments or achievements, even without the explicit goal, is underlined by the use of the indefinite article and the possibility of the pluralisation of the noun (Akimoto 1989, 6). Just as in the case of PVP, the use of VNP goes beyond aspectual motivation. The connotations most frequently suggested are "experience oriented" (Wierzbicka 1982, 759), "something experienced, got at, attained or enjoyed by the person denoted by the subject" (Visser 1963 [1970], 138). This underlying subjectivity may explain why as many as 12 out of 23 VNP in Wilde's play are used in the 1 st person (11 singular, and one plural).

There has been no comprehensive and systematic study of the grammatical environment of VNP so far. The comparison of the grammatical environment of all the instances of VNP and their corresponding SVP in Oscar Wilde's The Importance of Being Earnest shows no conclusive results as to the affinity of either structure for any specific grammatical environment, even if the small size of the basic and of the control samples (15 VNP and 20 SVP) is ignored. The table below shows an extremely low affinity of both constructions for the marked values of grammatical categories (negative polarity, non-present tenses, plural number).

\footnotetext{
9 That is why one can say have a peeltalk/think but not *have a urinatelconverselcontemplate. It should be noted, however, that Wierzbicka includes in her study only constructions in which the deverbal noun can be defined as a verb and does not have nominal properties.

10 Lareo's corpus consists of 200,000 words, 100,000 taken from scientific (mathematics and astrology) texts, 100,000 from fiction, both from the 19th century.
} 
TABLE 1. VNP and SVP structures in Wilde's The Importance of Being Earnest.

\begin{tabular}{|l|l|l|l|l|l|l|l|l|}
\hline & $\begin{array}{l}\text { Number } \\
\text { of VNP } \\
\text { in the } \\
\text { text }\end{array}$ & $\begin{array}{l}\text { Number } \\
\text { of SVP in } \\
\text { the text }\end{array}$ & $\begin{array}{l}\text { VNP in } \\
\text { negative } \\
\text { polariy }\end{array}$ & $\begin{array}{l}\text { SVP in } \\
\text { negative } \\
\text { polarity }\end{array}$ & $\begin{array}{l}\text { VNP in } \\
\text { non- } \\
\text { present } \\
\text { tenses }\end{array}$ & $\begin{array}{l}\text { SVP in } \\
\text { non- } \\
\text { present } \\
\text { tenses }\end{array}$ & $\begin{array}{l}\text { NVP in } \\
\text { plural } \\
\text { number }\end{array}$ & $\begin{array}{l}\text { SVP in } \\
\text { plural } \\
\text { number }\end{array}$ \\
\hline doubt & 5 & 2 & $3 / 5$ & $0 / 2$ & $0 / 5$ & $0 / 2$ & $0 / 5$ & $0 / 2$ \\
\hline intend & 1 & 7 & $1 / 1$ & $1 / 7$ & $0 / 1$ & $1 / 7$ & $0 / 1$ & $0 / 7$ \\
\hline know & 1 & 2 & $1 / 1$ & $2 / 2$ & $0 / 1$ & $1 / 1$ & $1 / 1$ & $0 / 2$ \\
\hline influence & 1 & 1 & $0 / 1$ & $0 / 1$ & $0 / 1$ & $0 / 1$ & $0 / 1$ & $0 / 1$ \\
\hline amuse & 1 & 3 & $0 / 1$ & $0 / 3$ & $0 / 1$ & $0 / 3$ & $0 / 1$ & $0 / 3$ \\
\hline prove & 1 & 2 & $0 / 1$ & $0 / 2$ & $0 / 1$ & $1 / 2$ & $0 / 1$ & $0 / 2$ \\
\hline notice & 2 & 1 & $1 / 2$ & $1 / 1$ & $0 / 2$ & $0 / 1$ & $0 / 2$ & $1 / 1$ \\
\hline consent & 2 & 1 & $1 / 2$ & $0 / 1$ & $0 / 2$ & $0 / 1$ & $0 / 2$ & $0 / 1$ \\
\hline allude & 1 & 1 & $0 / 1$ & $0 / \mathrm{q}$ & $0 / 1$ & $0 / 1$ & $0 / 1$ & $0 / 1$ \\
\hline
\end{tabular}

\section{Conclusion}

From the point of view of the theory of constructional iconicity, both periphrastic verbal phrases, PVP and VNP, validate the postulate that longer, more elaborate constructions are preferred when more complex meanings are to be conveyed. In contrast to non-committal simple verbs, PVP makes specific reference to the progressiveness and limited duration of an action, and is therefore not only formally, but also semantically more marked than SVP. Similarly, VNP adds telicity to the basic lexical meaning of the verbal phrase. Even when devoid of aspectual/telic content, both PVP and VNP come across as semantically more marked than SVP, albeit for their impressive function, such as emotional emphasis, goal-orientation, purposefulness of the agent, etc.

Despite the marked increase of PVP and VNP in Modern English, both constructions are still less frequent than corresponding SVP. As to the predictions ensuing from the theory of naturalness about the affinity of complex constructions for specific, more marked grammatical environment, some conclusions can be reached only for PVP. The relevance of the grammatical environment can be objectively assessed only if this environment is compared with the environment of semantically equivalent simple constructions. The interchangeability of PVP and SVP has been established for the Old English period, and the affinity of PVP for complex grammatical environment is clearly indicated then. Likewise, the semantic equivalency of VNP and SVP can be presumed only for the earliest stages of the emergence of VNP in Old English, but no corpus with a statistically significant number of VNP in Old English has been formed so far. In Modern English, the semantic equivalency of VNP and SVP is doubtful, but some bias of VNP towards complex (marked) environment should be indicated, albeit weakly pronounced. The fact that it is not may be interpreted in a number of ways: (1) the predictions of the theory of naturalness are valid only in the case of semantic equivalency of compared constructions; (2) the outer form of a construction is indicative of its semantic content, but it does not significantly affect its behaviour in a specific grammatical environment; (3) the expanded (elaborate) form of a construction may be the result of different processes (e.g. grammaticalisation, lexicalisation), the nature of which, and not only its result, determines the direction of the proliferation of the construction. 


\section{References}

Akimoto, Minoji. 1989. A Study of Verbo-Nominal Structures in English. Tokyo: Shinozaki Shorin.

Akimoto, Minoji, and Brinton, J. Laurel. 1999. “The Origin of the Composite Predicate in Old English.” In Collocational and Idiomatic Aspects of Composite Predicates in the History of English, edited by Minoji Akimoto and J. Laurel Brinton, 21-56. Amsterdam: Benjamins.

Algeo, John. 1995. "Having a Look at the Expanded Predicate." In The Verb in Contemporary English: Theory and Description, edited by Bas Aarts and Charles F. Meyer, 203-17. Cambridge: Cambridge University Press.

Bacchielli, Ronaldo. 1993. Termini Frasali Inglesi: Aspetti e Forme Pruduttivita Lessicale. Urbino: Quattro Venti.

Bolinger, Dwight. 1971. The Phrasal Verb in English. Cambridge, MA: Harvard University Press.

Cattel, Ray. 1984. Syntax and Semantics Vol.17. Composite Predicates in English. Sydney: Academic Press.

Croft, William. 1990 [2003]. Typology and Universals. Cambridge: Cambridge University Press.

Dennis, Leah. 1940. “The Progressive Tense: Frequency of Its Use in English.” PMLA 55 (3): 855-65.

Donegan, Patricia Jane. 1985. On the Natural Phonology of Vowels. New York, London: Garland.

Dotter, Franz. 1990. Nichtarbitrarität und Ikonizität in der Syntax. Hamburg: Buske.

Dressler, Wolfgang. 2000, "Naturalness.” In Morphologie: Ein internationals Handbuch zur Flexion und Wortbildung, edited by Geert Booij, Christian Lehmann, and Joachim Mugdan, 288-96. Berlin: Walter de Gruyter.

Dressler, Wolfgang U., Willi Mayerthaler, Oskar Panagl, and Wolfgang U.Wurzel. 1987. Leitmotifs in Natural Morphology. Amsterdam: Benjamins.

Elsness, Johan. 1994, "On the Progression of the Progressive in Early Modern English." ICAME Journal 18: $5-25$.

Givon, Thomas. 1985. "Iconicity, Isomorphism and Non-arbitrary Coding in Syntax." In Natural Syntax, edited by John Haiman, 187-219. Amsterdam: Benjamins.

—. 1991. "Markedness in Grammar: Distributional, Communicative and Cognitive Correlates of Syntactic Structures." Studies in Language 15 (2): 335-70. doi:10.1075/sl.15.2.05giv.

Goerlach, Manfred. 1919. Introduction to Early Modern English. Cambridge: Cambridge University Press.

Greenberg, Joseph. 1996. Language Universals, with Special Reference to Feature Hierarchies. The Hague: Mouton.

Haiman, John. 2000. "Iconicity." In Morphology: An International Handbook I, edited by Geert Booij, Joachim Mugdan, and Christian Lehmannj, 281-88. Berlin: Walter de Gruyter.

Haspelmath, Martin. 1999. "Why Is Grammaticalization Irreversible?” Linguistics 37 (6): 1043-68. doi:10.1515/ling.37.6.1043.

—. 2002. Understanding Morphology. London: Arnold.

—. 2006. "Against Markedness (and What to Replace It With)." Journal of Linguistics 42: 25-70. doi:10.1017/ S0022226705003683.

—. 2008. "Frequency vs. Iconicity in Explaining Grammatical Asymmetries." Cognitive Linguistics 19 (1): 1-33. doi:10.1515/COG.2008.001.

Havers, Wilhelm.1931. Handbuch der erklärenden Syntax. Ein Versuch zur Erfoschung der Bedinungen und Triebkräfte in Syntax und Stylistik. Heidelberg: Winter. 
Hickey, Raymond. 2012. “Internally and Externally Motivated Language Change.” In The Handbook of Historical Socilinguistics, edited by Juan Manuel Hernández-Compoy and Juan Camilo Conde-Silvestre, 401-21. Malden, MA: Wiley-Blackwell.

Iglesias-Rábade, Luis. 2001. "Composite Predicates in Middle English with the Verbs Nimen and Taken." Studia Neophilologica 73 (2): 143-63. doi:10.1080/003932701753401456.

Jakobson, Roman. 1932. "Zur Struktur des russischen Verbums.” In Charisteria Guilelmo Mathesio Quinquagenario a discipulis et Circuli Linguistici Pragensis sodalibus oblata, 74-86. Prague: Prague Linguistic Circle.

—. 1957 [1971]. "Shifters, Verbal Categories, and the Russian Verb. ”In Selected Writings (Vol. II), edited by Roman Jakobson, 130-47. The Hague: Mouton.

—. 1963 [1966]. "Implications of Language Universal for Linguistics." In Universals of Language, edited by Joseph Greenberg, 263-78. Cambridge, MA: MIT Press.

Jespersen, Otto.1931. A Modern English Grammar on Historical Principles 4. Copenhagen: Ejnar Munksgaard.

Klaeber, Friedrich. 1950. Beowulf and the Fight at Finnsburg, 3rd edition. Boston: D. C. Heat.

Lareo, Inés. 2008. "Analysing a Type of Collocation: Make Complex Predicates in Nineteenth-Century Science and Fiction." Revista Canaria de Estudios Ingleses 57: 165-80.

Lehmann, Christian. 1974. "Isomorphismus im sprachlichen Zeichen." Linguistic Workshop II: Arbeiten des Koelner Universalienprojekts 1973/4, 98-123. Muenchen: Fink.

Mair, Christian, and Marianne Hundt. 1995. "Why is the Progressive Becoming More Frequent in English." Zeitschrift fuer Anglistik und Amerikanistik 43: 111-22.

Matsumoto, Meiko. 1999. "Composite Predicates in Middle English." In Collocational and Idiomatic Aspects of Composite Predicates in the History of English, edited by Minoji Akimoto and Laurel J. Brinton, 58-97. Amsterdam: Benjamins.

—. 2005. "The Historical Development and Characteristics of Composite Predicates with Have and Take in English.” English Studies 86 (5): 439-56. doi:10.1080/00138380500164091.

Mayerthaler, Willi. 1981. Morphologische Natürlichkeit. Wiesbaden: Athenaion.

—. 1988. "System-Independent Morphological Naturalness." In Leitmotifs in Natural Morphology, edited by Wolfang U. Dressler, Willi Mayerthaler, Oskar Panagl, and Wolfgang U. Wurzel, 25-57. Amsterdam: Benjamins.

McWorther, John. 2002. "What Happened to English?” Diachronica 19 (2): 217-72. doi: 10.1075/ dia.19.2.02wha.

Mitchell, Bruce. 1985. Old English Syntax. Oxford: Clarendon.

Mossé, Ferdinand. 1938. Histoire de la forme périprastique être + participe prêsent en germanique. Paris: University of Paris.

Nickel, Gerhard. 1966. Die Expanded Form im Altenenglischen. Vorkkommen, Funktion und Herkunf beon/wesan + Partizip präsens. Neumuenster: Wacholtz.

—. 1968. "Complex Verbal Structures in English." International Review of Applied Linguistics in Language Teaching 6 (1-4): 1-21. doi:10.1515/iral.1968.6.1-4.1.

—. 1978. "Complex Verbal Structures in English." In Studies in Descriptive Linguistics, edited by Dieter Nehls, 63-83. Heidelberg: Julius Groos.

Olsson, Yngve. 1961. On the Syntax of the English Verb, with Special Reference to Have a Look and Similar Complex Structures. Göteborg: Elanders Boktryckeri Aktiebolag. 
Orešnik, Janez. 2004. Naturalness in (Morpho)syntax. English Examples. Ljubljana: Slovenska akademija znanosti in umetnosti.

Orešnik, Janez, Andrej Snedec, Karmen Teržan, and Frančiška Trobevšek Drobnak. 1990. "Introduction to the Subsequent Three papers in the Present Volume.” Linguistica 30: 5-12. doi:10.4312/linguistica.30.1.5-12.

Potter, Simeon. 1975. Changing English, 2nd edition. London: Andre Deutch.

Prince, Ellen F. 1972. “A Note on Aspect in English: the Take a Walk Construction.” In Transformationelle Analyse, edited by Senta Ploetz, 409-40. Frankfurt: Athenaum.

Quirk, Randolph, Sydney Greenbaum, Geoffrey Leech, and Jan Svartvik. 1985. Comprehensive Grammar of the English Language. London: Longman.

Ranta, Elina. 2006. "The 'Attractive Progressive - Why Use the -ing Form in English as a Lingua Franca." Nordic Journal of English Studies 5 (2): 95-116.

Rydén, Mats. 1979. An Introduction to the Historical Study of English Syntax. Stockholm: Almqvist \& Wiksell.

Stampe, David. 1979. A Dissertation on Natural Phonology. New York, London: Garland.

Sweet, Henry, ed. 1883 [1959]. King Alfred's Orosius. London: Truebner.

Traugott, Elizabeth Closs. 1972. A History of English Syntax: A Transformational Approach to the History of English Sentence Structure. New York: Holt, Reinhart \& Winston.

Trobevšek Drobnak, Frančiška. 1990. "Expanded Tenses in the Old English Orosius: A Syntactic Strengthening." Linguistica 30: 13-46. doi:10.4312/linguistica.30.1.13-46.

Trubezkoy, Nikolai. 1931. "Die phonologischen Systeme." Travaux du Cercle Lingustique de Prague 4: 96-116.

Visser, Frederic Th. 1963 [1970]. An Historical Syntax of the English Language. Part One: Syntactical Units with One Verb. Leiden: E. J. Brill.

Wierzbicka, Anna. 1982. "Why Can You Have a Drink When You Can't Have an Eat?” Language 58: 753-99.

Wurzel, Wolfgang U. 1994. "Morphology, Natural." In The Encyclopedia of Language and Linguistics, edited by R. E. Asher and J. M. Y. Simpson, 2590-98. Oxford: Pergamon Press.

—. 1998. “On Markedness." Theoretical Linguistics 24 (1): 53-71. doi:10.1515/thli.1998.24.1.53. 